\title{
Earth's oldest records of sea-floor spreading
}

Geologists have long-debated about when plate tectonics started on the planet. One of the key indicators has been whether or not fragments of oceanic crust, generated at sea-floor spreading centers, are preserved in the planet's oldest crust. New research integrating what has been learned about the variations in modern sea floor spreading environments with the geological record of the oldest preserved crust on Earth shows that many belts in these ancient terrains have striking similarities to the different tectonic settings that oceanic crust is generated within the modern plate tectonic framework The new study shows that there is at least as much variation between ancient Precambrian (greater than 2.5 billion years) and modern oceanic spreading processes as there is in the modern oceans. The paper by T. Kusky and colleagues from China, USA, and Canada synthesizes what is known about the variation in modern oceanic crust generated by plate tectonic processes, and compares this with similar features of Precambrian possible oceanic crust, and finds striking similarities to the newly recognized variation between tectonic environments for their origin. The record of oceanic crust generation, according to the new study, extends back until at least 3.8 billion years ago, the age of the most ancient rocks preserved on the planet. This work has important implications for understanding how the early Earth lost heat, which tectonic settings were dominant, and for the locations for the origin of life on Earth.

The work is presented in a paper published in issue 3 (March 2011) of SCIENCE CHINA Earth Sciences (Application of the Modern Ophiolite Concept with Special Reference to Precambrian Ophiolites) and can accessed at http://www.scichina.com:8080/sciDe/EN/volumn/current.shtml\#.

This work was supported by U.S. National Science Foundation Grants (02-07886 and 01-25925), the National Natural Science Foundation of China (91014002, 40821061) and the Ministry of Education of China (B07039).

See the article: Kusky T M, WANG L, Dilek Y, et al. Application of the modern ophiolite concept with special reference to Precambrian ophiolites. Sci China Earth Sci, 2011, 54: 315-341 